\title{
Feeding strategies and energy to protein ratio on tambaqui performance and physiology
}

\author{
Marcio Quara de Carvalho Santos(1), Mariana do Amaral Camara Lima(1), Luciana dos Santos(1), \\ Manoel Pereira-Filho(1), Eduardo Akifumi Ono(2) and Elizabeth Gusmão Affonso ${ }^{(1)}$
}

\begin{abstract}
(1)Instituto Nacional de Pesquisas da Amazônia, Coordenação de Tecnologia e Inovação, Avenida André Araújo, no 2.936, Caixa Postal 478, CEP 69060-001, Manaus, AM, Brazil. E-mail: marcioquara@hotmail.com, mana.amaral@gmail.com, lunacarioca@gmail.com, pmanoel@inpa.gov.br, pgusmao@inpa.gov.br (2)Universidade Nilton Lins, Avenida Prof. Nilton Lins, no 3.259, Parque das Laranjeiras, CEP 69065-030, Manaus, AM, Brazil. E-mail: onoedu@yahoo.com
\end{abstract}

\begin{abstract}
The objective of this work was to evaluate the effect of feed deprivation and refeeding with diets containing different energy to protein ratios $(\mathrm{E} / \mathrm{P})$ on the performance and physiology of juvenile tambaqui (Colossoma macropomum). A $4 \times 2$ factorial arrangement with three replicates was used, with four E/P ratios $\left(11.5,10.5,9.5\right.$, and $8.5 \mathrm{kcal} \mathrm{g}^{-1}$ digestible energy per protein) and two feeding regimens (with and without deprivation), during 60 days. Fish from the food-deprived group were fasted for 14 days and refed from the fifteenth to the sixtieth day, whereas the remaining fish were fed for 60 days. At the end of the experimental period, weight of fish subjected to food deprivation was lower than that of those continuously fed; however, this condition did not influence the physiological parameters analyzed. Tambaqui fed $11.5 \mathrm{kcal} \mathrm{g}^{-1}$ achieved lower final weight than those fed with the other diets, in both regimens. Among the physiological parameters, only plasma protein presented significant increase in fish fed $8.5 \mathrm{kcal} \mathrm{g}^{-1}$, in both feeding regimens, probably due to the higher dietary protein concentration. These results indicate that fish show a partial compensatory growth, and that $10.5 \mathrm{kcal} \mathrm{g}^{-1}$ can be recommended for the diet of juvenile tambaqui.
\end{abstract}

Index terms: Colossoma macropomum, blood parameters, energy/protein requirement, food restriction.

\section{Estratégias alimentares e relação entre energia e proteína sobre o desempenho e a fisiologia de tambaqui}

\begin{abstract}
Resumo - O objetivo deste trabalho foi avaliar o efeito da privação alimentar e da realimentação com dietas contendo diferentes relações entre energia e proteína (E/P) sobre o desempenho e a fisiologia de juvenis de tambaqui (Colossoma macropomum). Utilizou-se arranjo fatorial $4 \times 2$ com três repetições, com quatro relações $\mathrm{E} / \mathrm{P}\left(11,5,10,5,9,5\right.$ e $8,5 \mathrm{kcal} \mathrm{g}^{-1}$ de energia digestível por proteína) e dois regimes alimentares (com e sem privação), durante 60 dias. Peixes do grupo com privação alimentar permaneceram em jejum por 14 dias e foram realimentados do décimo quinto ao sexagésimo dia, enquanto os demais foram alimentados por 60 dias. Ao final do período experimental, o peso dos peixes submetidos à privação alimentar foi menor do que o dos alimentados continuamente; entretanto, esta condição não influenciou os parâmetros fisiológicos avaliados. Tambaquis alimentados com 11,5 $\mathrm{kcal} \mathrm{g}^{-1}$ obtiveram menor peso que os alimentados com as demais dietas, em ambos os regimes. Entre os parâmetros fisiológicos, apenas a proteína plasmática apresentou aumento significativo nos peixes alimentados com $8,5 \mathrm{kcal} \mathrm{g}^{-1}$, em ambos os regimes alimentares, provavelmente em razão da maior concentração de proteína na dieta. Esses resultados mostram que os peixes apresentam crescimento compensatório parcial em todos os tratamentos, e que $10,5 \mathrm{kcal} \mathrm{g}^{-1}$ pode ser recomendada para a dieta de juvenis de tambaqui.
\end{abstract}

Termos para indexação: Colossoma macropomum, parâmetros sanguíneos, exigência energia/proteína, restrição alimentar.

\section{Introduction}

Tambaqui (Colossoma macropomum) is the most prominent farmed, native fish species and the third most cultivated in Brazilian aquaculture. In 2010, the national production of tambaqui was $54,313.1 \mathrm{Mg}$, representing $14 \%$ of all fish from continental fish farming (Brasil, 2012). The success of rearing this species is due to particular characteristics, including fast growth, rusticity, tolerance to low water dissolved oxygen concentration, suitability to artificial reproduction techniques, and good acceptance of formulated diets (Silva et al., 2007).

However, one of the factors that makes fish farming unattractive to investors is the high feed price (Oliveira 
et al., 2012), especially in the Amazon region where most food inputs are imported. According to Partos (2010), feed represents 50 to $70 \%$ of total production costs.

A strategy to reduce feeding costs is to determine fish nutritional requirements, mainly protein need, which is the most expensive nutrient in the diet (Santos et al., 2010). The protein requirement of a species is the minimum amount of amino acids that generates the maximum growth possible and can be influenced by protein source, dietary energy to protein $(\mathrm{E} / \mathrm{P})$ ratio, fish size, and water temperature (Pezzato et al., 2004). Therefore, determining the ideal $\mathrm{E} / \mathrm{P}$ ratio is as important as knowing the fish protein requirement. An unbalanced feed E/Pratio may result in low performance of fish production systems (Lovell, 1989). Excessive non-protein feed energy may inhibit voluntary food consumption before sufficient amounts of amino acids are ingested, whereas insufficient non-protein dietary energy will result in the use of protein as an energy source, compromising fish growth and immune system (National Research Council, 1993; Aliyu-Paiko et al., 2010).

Food deprivation is a feed management practice that has been extensively studied. It consists of maintaining animals in inanition for a certain period, aiming for their compensatory growth. According to Jobling (2010), compensatory growth can be defined as a physiological process in which the body accelerates growth after a period of restricted development, generally caused by a reduced food intake, in order to reach the weight of the animals not subjected to food restriction.

Several studies have focused on compensatory growth in fish (Wieser et al., 1992; Tian \& Qin, 2003; Turano et al., 2008; Wang et al., 2009). Ituassú et al. (2004) subjected tambaqui to different periods of deprivation and found that after a restriction of up to 14 days the species showed total compensatory growth and higher body protein deposition when feed was restored. Santos et al. (2010) kept juvenile tambaqui unfed for 14 days and observed that protein requirements did not increase after a period of food restriction. These authors also found that animals fed ration containing $9.5 \mathrm{kcal} \mathrm{g}^{-1}$ digestible energy per protein presented best carcass composition after feed restriction, with lower fat content and higher body protein deposition.

Despite the large number of studies on food deprivation, only growth performance and fish body composition have been analyzed. No monitoring has been reported on the physiological changes in fish during the compensatory growth period or on the risks associated to fast growth (Ali et al., 2003).

The objective of this work was to evaluate the effect of feed deprivation and refeeding with diets containing different $\mathrm{E} / \mathrm{P}$ ratios on the performance and physiology of juvenile tambaqui.

\section{Materials and Methods}

Juvenile tambaqui were obtained from a commercial fish farm located in Rio Preto da Eva, AM, Brazil, transported to Coordenação de Tecnologia e Inovação (Coti), at Instituto Nacional de Pesquisas da Amazônia, acclimated, and fed commercial extruded feed containing $32 \%$ crude protein twice daily for a seven-day period. The experiment was carried out at the Coti laboratory between October and December 2006.

Three hundred and eighty four fish $(50.3 \pm 8.0 \mathrm{~g})$ were distributed in 24 PVC tanks $(310 \mathrm{~L})$ with continuous aeration and $10 \%$ daily water exchange, at a density of 16 fish per tank. A randomized block design was used, in a $4 \times 2$ factorial arrangement with three replicates, using experimental pelletized diets with four energy to protein ratios $\left(11.5,10.5,9.5\right.$, and $8.5 \mathrm{kcal} \mathrm{g}^{-1}$ digestible energy per crude protein) and two feeding regimens (with and without deprivation) (Table 1).

Food deprivation was done during a period of 14 days, according to Ituassú et al. (2004), and fish were fed from the fifteenth to the sixtieth day. Fish without feed deprivation were continuously fed along the 60 day trial.

Fish were fed the experimental diets twice daily to apparent satiation, during the 60 day period. At the beginning and the end of the experiment, biometric evaluation of all fish was done. For blood parameter analysis, blood samples were collected from five fish of each experimental unit at the end of the experimental period.

Fish were anesthetized with $100 \mathrm{mg} \mathrm{L}^{-1}$ benzocaine before blood extraction, and samples were drawn by caudal puncture with syringe containing 10\% EDTA. The following parameters were analyzed: hematocrit (Ht), by the microhematocrit method using heparinized capillary tubes; erythrocyte counting (RBC), in a Neubauer chamber; and hemoglobin $(\mathrm{Hb})$, total plasma protein (TPP), and plasma glucose (Gl) concentrations, 
determined by specific commercial kits supplied by Doles (Goiânia, GO, Brazil) (Tavares-Dias \& Moraes, 2004). The hematimetric indexes mean corpuscular volume (MCV) and mean corpuscular hemoglobin concentration (MCHC) were calculated from the $\mathrm{RBC}, \mathrm{Ht}$, and $\mathrm{Hb}$ of each individual (Wintrobe, 1934).

During the experimental period, water physical and chemical parameters were analyzed in all tanks. The following were measured daily: dissolved oxygen and electrical conductivity, with a YSI 85 digital meter (YSI Incorporated, Yellow Springs, OH, USA); and $\mathrm{pH}$ and temperature, using a YSI 60 handheld phmeter (YSI Incorporated, Yellow Springs, OH, USA). Total ammonia and nitrite concentrations were determined twice a week by spectrophotometric methods according to Verdouw et al. (1978) and Boyd \& Tucker (1992), respectively.

The comparison between weight of different treatments and basal values was done using Student's $\mathrm{t}$ test, at $5 \%$ probability. Results from treatments and water quality were evaluated by two-way analysis of variance using diets and feeding regimens as factors. Means of treatments with significant differences were compared by Tukey's test, at 5\% probability.

Table 1. Composition of the experimental diets for tambaqui (Colossoma macropomum) with different energy to protein $(\mathrm{E} / \mathrm{P})$ ratios.

\begin{tabular}{|c|c|c|c|c|}
\hline \multirow[t]{2}{*}{$\begin{array}{l}\text { Ingredient } \\
(\%)\end{array}$} & \multicolumn{4}{|c|}{$\begin{array}{c}\text { Experimental diets } \\
\left(\mathrm{kcal} \mathrm{g}^{-1} \text { digestible energy per protein }\right)^{-}\end{array}$} \\
\hline & 11.5 & 10.5 & 9.5 & 8.5 \\
\hline Fish meal & 4.0 & 7.5 & 12.9 & 14.8 \\
\hline Soybean meal & 38.0 & 42.2 & 45.0 & 53.0 \\
\hline Wheat middlings & 19.0 & 19.0 & 15.0 & 11.0 \\
\hline Corn & 37.2 & 28.0 & 23.0 & 17.0 \\
\hline Soybean oil & 1.0 & 2.5 & 3.3 & 3.4 \\
\hline Vitamin and mineral supplement ${ }^{(1)}$ & 0.8 & 0.8 & 0.8 & 0.8 \\
\hline Total & 100.0 & 100.0 & 100.0 & 100.0 \\
\hline Crude protein $(\%)$ & 28.2 & 31.9 & 36.0 & 40.0 \\
\hline Digestible energy $\left(\mathrm{kcal} 100 \mathrm{~g}^{-1}\right)^{(2)}$ & 324.9 & 333.8 & 340.7 & 340.2 \\
\hline $\mathrm{E} / \mathrm{P}$ ratio & 11.5 & 10.5 & 9.5 & 8.5 \\
\hline
\end{tabular}

${ }^{(1)}$ Composition per kg of product: folic acid, $250 \mathrm{mg}$; pantothenic acid, 5,000 $\mathrm{mg}$; biotin, $125 \mathrm{mg}$; cobalt, $25 \mathrm{mg}$; copper, 2,000 mg; iron, 13,820 mg; iodine, $100 \mathrm{mg}$; manganese, 3,750 mg; niacin, 5,000 mg; selenium, $75 \mathrm{mg}$; zinc, $874.95 \mathrm{mg}$; vitamin A, 1,000,000 UI; vitamin B1, 1,250 mg; vitamin B12, 3,750 mg; vitamin B2, 2,500 mg; vitamin B6, 2,485 mg; vitamin C, 28,000 mg; vitamin D3, 500,000 UI; vitamin E, 20,000 UI; vitamin K3, $500 \mathrm{mg}$. ${ }^{(2)}$ Digestible energy estimated based on the apparent digestibility coefficient of Piaractus mesopotamicus (Abimorad \& Carneiro, 2004).

\section{Results and Discussion}

Significant differences were observed between the two feeding regimes regarding water quality (dissolved oxygen, electrical conductivity, and total ammonia) (Table 2). Dissolved oxygen was higher in tanks in which fish were deprived of food, whereas electrical conductivity and ammonia showed inverse relation in these tanks. The variations observed in the levels of dissolved oxygen and electrical conductivity during the deprivation period were similar to those found by Ituassú et al. (2004). These results can be attributed to the deprivation period imposed on fish, since in the tanks with deprivation there was a lower production and release of fecal organic matter, reducing the amount of ammonia in the water. Moreover, the absence of residues of ration in the water caused a reduction in oxygen consumption by fish and a lower electrical conductivity in the tank water.

In the refeeding period, water quality presented significant variations in $\mathrm{pH}$, electrical conductivity, and total ammonia (Table 2). These variations were related to the different rations provided, and values increased with decreasing feed $\mathrm{E} / \mathrm{P}$ ratio and increasing feed protein levels. The variations in ammonia levels are probably due to the decrease in the $\mathrm{E} / \mathrm{P}$ ratio, which induces fish to use protein as an energy source, increasing the release of ammonia nitrogen (Lovell, 1989; Wilkie, 2002). Changes in $\mathrm{pH}$ and electrical conductivity are associated to the increasing levels of ionized ammonia in the water, which has an alkaline reaction (Kubitza, 2003).

Despite the differences observed, the variation range was minor and all water physical and chemical parameters were in the comfort range for the production of tropical fish (Kubitza, 2003) and of tambaqui (Aride et al., 2004).

According to Ali et al. (2003), animals can show several types of compensatory growth. Overcompensation occurs when animals subjected to fasting reach a size larger than that of the continuously fed animals, after refeeding. Total compensation occurs when fasted animals reach, after refeeding, the same size of the animals constantly fed. In partial compensation, after food deprivation, the animals do not reach the same size of the continuously fed animals, whereas, in no compensation, size is not recovered after food deprivation.

Pesq. agropec. bras., Brasília, v.48, n.8, p.955-961, ago. 2013 DOI: 10.1590/S0100-204X2013000800021 
Fish final weight was significantly different in all treatments when compared to initial weight (Figure 1). After 60 days, fish with no food deprivation presented a higher weight gain than food deprived animals, regardless of the diet. This result indicates a partial compensatory growth, since the animals deprived of food did not reach the same weight of the continuously fed animals.

Ituassú et al. (2004) reported that tambaqui subjected to 14 days of food deprivation showed total compensatory growth after 84 days of refeeding with ration containing $36 \%$ crude protein, and that, after periods of 21 and 28 days of deprivation, the animals presented partial compensatory growth. Turano et al. (2008) subjected hybrid striped bass (Morone chrysops $\mathrm{x}$ Morone saxatilis) to three weeks of food restriction, followed by three and six weeks of refeeding, and found that fish showed partial compensatory growth, independently of the refeeding period. Wang et al. (2009) observed that Nile tilapia (Oreochromis niloticus) subjected to cycles of one to four weeks of food deprivation, followed by two to eight weeks of refeeding, showed partial compensatory growth. According to Tian \& Qin (2003), total compensation is possible only when the body mass of food deprived animals is not inferior to $60 \%$ of that of continuously fed fish.

Regardless of the feeding regimen, fish fed 10.5, 9.5 , and $8.5 \mathrm{kcal} \mathrm{g}^{-1}$ digestible energy per protein presented higher average final weight than fish fed $11.5 \mathrm{kcal} \mathrm{g}^{-1}$ (Figure 1). These results show that the diet with $11.5 \mathrm{kcal} \mathrm{g}^{-1}$ did not meet the minimum protein requirement of fish. It was also verified that fish subjected to food deprivation did not increase protein demand.

According to Wieser et al. (1992), four physiological phases occur during the period of food deprivation. The first is the stress phase, characterized by hyperactivity of the animal in search of food. The second is the transition phase, in which there is a reduction in the respiratory rate and glycolytic and glycogenic activity in the swimming muscles. The third phase is adaptation, with stabilization of the metabolic rate at a low level. If deprivation continues, an increase occurs in the replacement of lipids by protein as an energy source. The final phase is recovery, marked by the rapid increase in growth and oxygen consumption rates.

Among the blood parameters analyzed, only total plasma protein presented significant increase in fish fed $8.5 \mathrm{kcal} \mathrm{g}^{-1}$ digestible energy per protein, when

Table 2. Water dissolved oxygen (DO), temperature, electric conductivity (EC), $\mathrm{pH}$, total ammonia, and nitrite concentration of the experimental tanks with tambaqui (Colossoma macropomum) under two feeding regimes: food deprivation and continuous feeding with four energy to protein ratios ( $\mathrm{kcal} \mathrm{g}^{-1}$ digestible energy per protein) during the first 14 days and the refeeding period $^{(1)}$.

\begin{tabular}{|c|c|c|c|c|c|c|c|}
\hline Diet & Regime & $\mathrm{DO}\left(\mathrm{mg} \mathrm{L}^{-1}\right)$ & Temperature $\left({ }^{\circ} \mathrm{C}\right)$ & $\mathrm{EC}\left(\mu \mathrm{S} \mathrm{cm}^{-1}\right)$ & $\mathrm{pH}$ & Total ammonia $\left(\mathrm{mg} \mathrm{L}^{-1}\right)$ & Nitrite $\left(\mathrm{mg} \mathrm{L}^{-1}\right)$ \\
\hline & \multicolumn{7}{|c|}{ Food deprivation -0 to $14^{\text {th }}$ day } \\
\hline \multirow{2}{*}{11.5} & DP & $6.1 \pm 0.3 \mathrm{~A}$ & $27.9 \pm 0.1$ & $18.3 \pm 0.6 \mathrm{~A}$ & $4.8 \pm 0.1$ & $0.17 \pm 0.09 \mathrm{~A}$ & $0.001 \pm 0.003$ \\
\hline & $\mathrm{CF}$ & $4.7 \pm 0.2 \mathrm{~B}$ & $27.0 \pm 0.1$ & $21.8 \pm 0.6 \mathrm{~B}$ & $5.1 \pm 0.1$ & $0.23 \pm 0.09 \mathrm{~B}$ & $0.007 \pm 0.030$ \\
\hline \multirow{2}{*}{10.5} & DP & $6.0 \pm 0.4 \mathrm{~A}$ & $27.1 \pm 0.1$ & $18.7 \pm 0.4 \mathrm{~A}$ & $4.9 \pm 0.3$ & $0.16 \pm 0.05 \mathrm{~A}$ & $0.004 \pm 0.007$ \\
\hline & $\mathrm{CF}$ & $4.8 \pm 0.1 \mathrm{~B}$ & $26.9 \pm 0.1$ & $23.0 \pm 1.0 \mathrm{~B}$ & $5.2 \pm 0.2$ & $0.42 \pm 0.30 \mathrm{~B}$ & $0.004 \pm 0.030$ \\
\hline \multirow{2}{*}{9.5} & DP & $6.4 \pm 0.1 \mathrm{~A}$ & $27.0 \pm 0.1$ & $18.4 \pm 0.4 \mathrm{~A}$ & $4.9 \pm 0.2$ & $0.12 \pm 0.05 \mathrm{~A}$ & $0.000 \pm 0.0001$ \\
\hline & $\mathrm{CF}$ & $4.9 \pm 0.3 \mathrm{~B}$ & $27.0 \pm 0.1$ & $23.2 \pm 0.5 \mathrm{~B}$ & $5.2 \pm 0.1$ & $0.57 \pm 0.05 \mathrm{~B}$ & $0.008 \pm 0.002$ \\
\hline \multirow{2}{*}{8.5} & DP & $6.2 \pm 0.2 \mathrm{~A}$ & $27.0 \pm 0.1$ & $18.4 \pm 0.9 \mathrm{~A}$ & $4.8 \pm 0.1$ & $0.16 \pm 0.03 \mathrm{~A}$ & $0.001 \pm 0.004$ \\
\hline & $\mathrm{CF}$ & $4.9 \pm 0.2 \mathrm{~B}$ & $27.0 \pm 0.1$ & $22.6 \pm 1.3 \mathrm{~B}$ & $5.1 \pm 0.1$ & $0.59 \pm 0.15 \mathrm{~B}$ & $0.040 \pm 0.050$ \\
\hline & \multicolumn{7}{|c|}{ Refeeding period -15 to $60^{\text {th }}$ day } \\
\hline \multirow{2}{*}{11.5} & DP & $5.7 \pm 0.1$ & $27.1 \pm 0.1$ & $22.9 \pm 1.0 \mathrm{a}$ & $5.1 \pm 0.1 \mathrm{a}$ & $0.6 \pm 0.1 \mathrm{a}$ & $0.01 \pm 0.003$ \\
\hline & $\mathrm{CF}$ & $5.7 \pm 0.2$ & $27.2 \pm 0.1$ & $22.0 \pm 0.7 \mathrm{a}$ & $5.0 \pm 0.1 \mathrm{a}$ & $0.6 \pm 0.1 \mathrm{a}$ & $0.01 \pm 0.002$ \\
\hline \multirow{2}{*}{10.5} & DP & $5.8 \pm 0.2$ & $27.0 \pm 0.1$ & $26.3 \pm 2.5 \mathrm{ab}$ & $5.3 \pm 0.3 b$ & $0.9 \pm 0.2 \mathrm{ab}$ & $0.01 \pm 0.002$ \\
\hline & $\mathrm{CF}$ & $5.7 \pm 0.1$ & $27.0 \pm 0.1$ & $26.0 \pm 2.4 \mathrm{ab}$ & $5.3 \pm 0.2 \mathrm{~b}$ & $0.8 \pm 0.3 \mathrm{ab}$ & $0.01 \pm 0.003$ \\
\hline \multirow{2}{*}{9.5} & DP & $5.8 \pm 0.3$ & $27.1 \pm 0.1$ & $27.0 \pm 3.2 \mathrm{~b}$ & $5.2 \pm 0.2 \mathrm{~b}$ & $1.1 \pm 0.5 \mathrm{~b}$ & $0.01 \pm 0.006$ \\
\hline & $\mathrm{CF}$ & $5.5 \pm 0.3$ & $27.0 \pm 0.1$ & $28.6 \pm 3.5 b$ & $5.4 \pm 0.1 \mathrm{~b}$ & $1.1 \pm 0.2 b$ & $0.01 \pm 0.001$ \\
\hline \multirow{2}{*}{8.5} & DP & $5.6 \pm 0.3$ & $27.0 \pm 0.1$ & $31.1 \pm 2.3 b$ & $5.4 \pm 0.1 \mathrm{~b}$ & $1.3 \pm 0.1 \mathrm{~b}$ & $0.01 \pm 0.005$ \\
\hline & $\mathrm{CF}$ & $5.7 \pm 0.2$ & $27.1 \pm 0.1$ & $28.1 \pm 3.9 b$ & $5.3 \pm 0.1 \mathrm{~b}$ & $1.2 \pm 0.3 \mathrm{~b}$ & $0.01 \pm 0.002$ \\
\hline
\end{tabular}

(1)Uppercase letters indicate significant differences between feeding regimes on the same diet by Tukey's test, at 5\% probability; lowercase letters indicate significant differences among diets on the same feeding regime by Tukey's test, at $5 \%$ probability. DP, deprivation, $\mathrm{CF}$, continuous feeding. Mean $\pm \mathrm{SD}, \mathrm{n}=16$. 
compared to those fed 11.5 and $10.5 \mathrm{kcal} \mathrm{g}^{-1}$, for both feeding regimens (Figure 2). This increase is probably due to the high concentration of protein in the diet of that experimental group (Table 1), corroborating with the data from Abdel-Tawwab et al. (2005), who also observed increase in the plasma protein concentration in Nile tilapia fed 35 and $45 \%$ crude protein, and

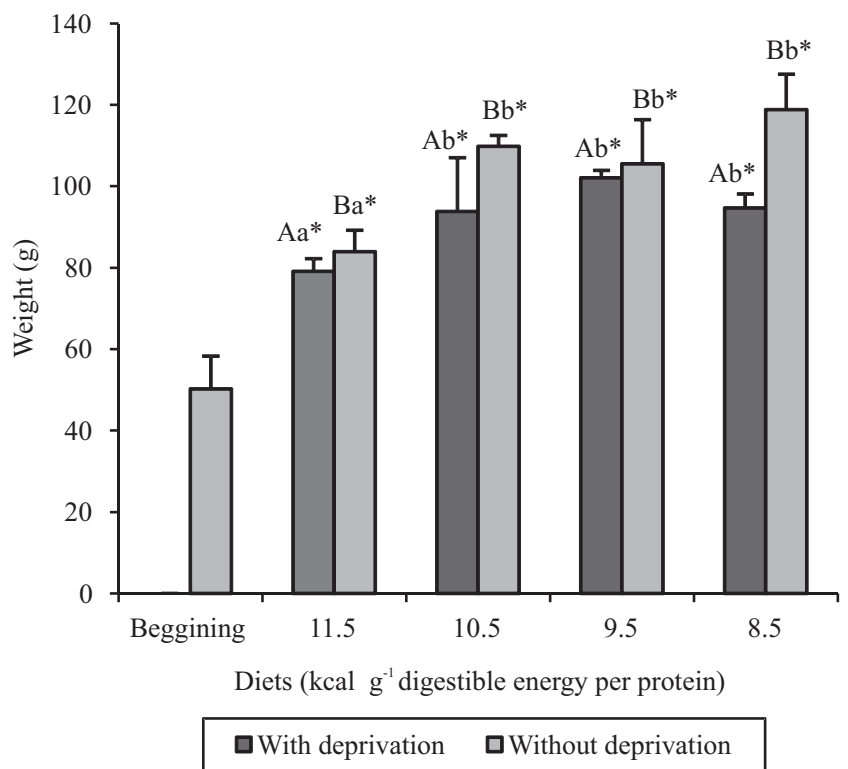

Figure 1. Mean weight of tambaqui (Colossoma macropomum) subjected to feed deprivation and refed diets with four energy to protein ratios, $n=48$. Uppercase letters indicate significant differences between feeding regimes on the same diet; lowercase letters indicate significant differences among diets on the same feeding regime. *Significant differences compared to basal value. All differences were evaluated by Tukey's test, at $5 \%$ probability. from Bicudo et al. (2010), who found similar pattern for pacu (Piaractus mesopotamicus) fed 34 and 38\% crude protein.

The other blood parameters analyzed showed no significant differences among treatments at the end of the experiment (Table 3 ). This result suggests that the 14 day food deprivation period and the subsequent refeeding with diets containing different protein levels did not change fish physiological conditions. Similar results were found by Congleton \& Wagner (2006), who reported that physiological parameters

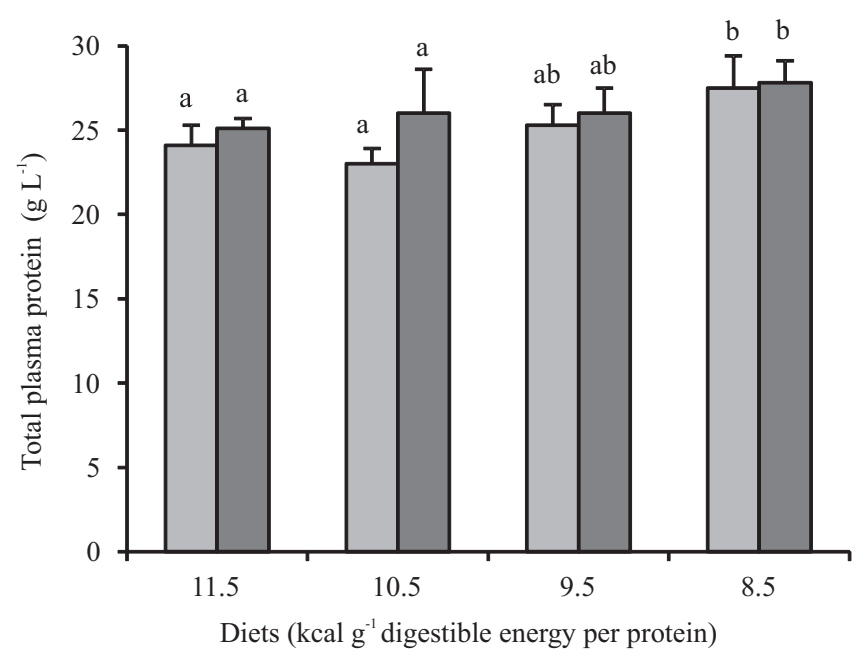

$\square$ With deprivation $\square$ Without deprivation

Figure 2. Plasma total protein concentration of tambaqui (Colossoma macropomum) subjected to feed deprivation and refed diets with four energy to protein ratios, $n=15$ per treatment. Lowercase letters indicate significant differences among diets on the same feeding regime by Tukey's test, at $5 \%$ probability.

Table 3. Hematocrit (Ht), hemoglobin (Hb), red blood cell (RBC), mean corpuscular volume (MCV), mean corpuscular hemoglobin concentration (MCHC), and plasma glucose (Gl) of juvenile tambaqui (Colossoma macropomum) subjected to 14 day food deprivation and refed with diets containing four energy to protein ratios in the $\operatorname{diet}^{(1)}$.

\begin{tabular}{|c|c|c|c|c|c|c|c|}
\hline Diet (kcal g-1 digestible energy per protein) & Regime & Ht $(\%)$ & $\mathrm{Hb}\left(\mathrm{g} \mathrm{dL}^{-1}\right)$ & $\mathrm{RBC}\left(\times 10^{6} \mu \mathrm{L}^{-1}\right)$ & MCV (fL) & $\mathrm{MCHC}\left(\mathrm{g} \mathrm{dL}^{-1}\right)$ & $\mathrm{Gl}\left(\mathrm{mmol} \mathrm{L}^{-1}\right)$ \\
\hline \multirow{2}{*}{11.5} & $\mathrm{DP}$ & $38.7 \pm 2.1$ & $12.7 \pm 0.2$ & $2.3 \pm 0.1$ & $169.5 \pm 4.5$ & $33.0 \pm 1.0$ & $4.4 \pm 0.7$ \\
\hline & $\mathrm{CF}$ & $38.3 \pm 2.5$ & $13.2 \pm 0.9$ & $2.3 \pm 0.1$ & $168.2 \pm 8.7$ & $34.7 \pm 2.1$ & $4.1 \pm 0.7$ \\
\hline \multirow{2}{*}{10.5} & DP & $35.5 \pm 0.4$ & $12.1 \pm 0.6$ & $2.2 \pm 0.1$ & $164.4 \pm 1.7$ & $34.3 \pm 1.2$ & $3.8 \pm 0.5$ \\
\hline & $\mathrm{CF}$ & $37.6 \pm 2.5$ & $12.6 \pm 0.6$ & $2.2 \pm 0.1$ & $173.7 \pm 3.6$ & $33.5 \pm 1.5$ & $3.7 \pm 0.2$ \\
\hline \multirow{2}{*}{9.5} & DP & $36.3 \pm 1.6$ & $12.6 \pm 0.7$ & $2.1 \pm 0.1$ & $171.7 \pm 5.8$ & $35.1 \pm 3.4$ & $4.1 \pm 0.6$ \\
\hline & $\mathrm{CF}$ & $37.0 \pm 1.2$ & $12.0 \pm 1.0$ & $2.2 \pm 0.1$ & $171.7 \pm 6.3$ & $32.6 \pm 2.1$ & $3.8 \pm 0.5$ \\
\hline \multirow{2}{*}{8.5} & DP & $37.5 \pm 1.4$ & $12.4 \pm 1.1$ & $2.2 \pm 0.1$ & $174.7 \pm 4.4$ & $33.1 \pm 3.2$ & $4.2 \pm 0.4$ \\
\hline & $\mathrm{CF}$ & $37.1 \pm 1.4$ & $12.1 \pm 0.5$ & $2.2 \pm 0.2$ & $167.9 \pm 9.2$ & $32.6 \pm 0.6$ & $4.0 \pm 0.6$ \\
\hline
\end{tabular}

${ }^{(1)} \mathrm{DP}$, deprivation; $\mathrm{CF}$, continuous feeding. Mean $\pm \mathrm{SD}, \mathrm{n}=15$ fish per treatment. 
of rainbow trout (Oncorhynchus mykiss) and Chinook salmon (O. tshawytscha), subjected to 21 and 35 days of food deprivation, returned to basal levels after ten days of refeeding. Furné et al. (2012) also observed the reestablishment of the physiological parameters of Adriatic sturgeon (Acipenser naccarii) and rainbow trout kept fasted for 72 days and refed during 60 days.

The physiological data obtained in the present study are in accordance to Ali et al. (2003), who suggest that the ability of fish to present compensatory growth after food deprivation does not depend solely on the species capacity to use its endogenous reserves during starvation, but is specially related to the reestablishment of homeostasis during the refeeding period.

\section{Conclusions}

1. The 14 day period of food deprivation does not affect the physiological profile of juvenile tambaqui (Colossoma macropomum) and improves water quality, but negatively affects animal weight gain after refeeding.

2. Protein and energy demand of juvenile tambaqui do not increase due to food deprivation, and $10.5 \mathrm{kcal} \mathrm{g}^{-1}$ digestible energy per protein can be recommended for the diet of juvenile tambaqui.

\section{Acknowledgements}

To Conselho Nacional de Desenvolvimento Científico e Tecnológico (CNPq), to Fundação de Amparo à Pesquisa do Estado do Amazonas (Fapeam), and to Instituto Nacional de Pesquisas da Amazônia (Inpa), for financial support.

\section{References}

ABDEL-TAWWAB, M.; MOUSA, M.A.A.; SHARAF, S.M.; AHMAD, M.H. Effect of crowding stress on some physiological functions of Nile tilapia, Oreochromis niloticus (L.) fed different dietary protein levels. International Journal of Zoological Research, v.1, p.41-47, 2005. DOI: 10.3923/ijzr.2005.41.47.

ABIMORAD, E.G.; CARNEIRO, D.J. Fecal collection methods and determination of crude protein and of gross energy digestibility coefficients of feedstuffs for Pacu, Piaractus mesopotamicus (Holmberg, 1887). Revista Brasileira de Zootecnia, v.33, p.1101-1109, 2004. DOI: 10.1590/S1516-35982004000500001.

ALI, M.; NICIEZA, A.; WOOTTON, R.J. Compensatory growth in fishes: a response to growth depression. Fish and Fisheries, v.4, p.147-190, 2003. DOI: 10.1046/j.1467-2979.2003.00120.x.

ALIYU-PAIKO, M.; HASHIM, R.; SHU-CHIEN, A.C. Influence of dietary lipid/protein ratio on survival, growth, body indices and digestive lipase activity in Snakehead (Channa striatus, Bloch 1793) fry reared in re-circulating water system. Aquaculture Nutrition, v.16, p.466-474, 2010. DOI: 10.1111/j.1365-2095.200 9.00683.x.

ARIDE, P.H.R.; ROUBACH, R.; VAL, A.L. Water $\mathrm{pH}$ in Central Amazon and its importance for tambaqui (Colossoma macropomum) culture. World Aquaculture, v.35, p.24-27, 2004.

BICUDO, A.J.A.; SADO, R.Y.; CYRINO, J.E.P. Growth performance and body composition of Pacu Piaractus mesopotamicus (Holmberg 1887) in response to dietary protein and energy levels. Aquaculture Nutrition, v.16, p.213-222, 2010. DOI: 10.1111/j.1365-2095.2009.00653.x.

BRASIL. Ministério da Pesca e Aquicultura. Boletim estatístico da pesca e aquicultura: Brasil 2010. Brasília: Ministério da Pesca e Aquicultura, 2012. 129p.

BOYD, C.E.; TUCKER, C.S. Water quality and pond soil analyses for aquaculture. Auburn: Alburn University, 1992.300p.

CONGLETON, J.L.; WAGNER, T. Blood-chemistry indicators of nutritional status in juvenile salmonids. Journal of Fish Biology, v.69, p.473-490, 2006. DOI: 10.1111/j.1095-8649.2006.01114.x.

FURNÉ, M.; MORALES, A.E.; TRENZADO, C.E.; GARCIA-GALLEGO, M.; HIDALGO, M.C.; DOMEZAIN, A.; RUS, A.S. The metabolic effects of prolonged starvation and refeeding in sturgeon and rainbow trout. Journal of Comparative Physiology B: Biochemical Systemic and Environmental Physiology, v.182, p.63-76, 2012. DOI: 10.1007/ s00360-011-0596-9.

ITUASSÚ, D.R.; SANTOS, G.R.S. dos; ROUBACH, R.; PEREIRA-FILHO, M. Desenvolvimento de tambaqui submetido a períodos de privação alimentar. Pesquisa Agropecuária Brasileira, v.39, p.1199-1203, 2004. DOI: 10.1590/ S0100-204X2004001200006.

JOBLING, M. Are compensatory growth and catch-up growth two sides of the same coin? Aquaculture International, v.18, p.501-510, 2010. DOI: 10.1007/s10499-009-9260-8.

KUBITZA, F. Qualidade da água no cultivo de peixes e camarões. Jundiaí: Acqua Imagem, 2003. 229p.

LOVELL, T. Nutrition and feeding of fish. New York: Van Nostrand Reinhold, 1989. 260p. DOI: 10.1007/978-1-4757-1174-5.

NATIONAL RESEARCH COUNCIL. Nutrient requirements of fish. Washington: National Academy Press, 1993. 114p.

OLIVEIRA, A.M. de; SILVA, M. de N.P.; ALMEIDA-VAL, V.M.F. de; VAL, A.L. Caracterização da atividade de piscicultura nas mesorregiões do Estado do Amazonas, Amazônia brasileira. Revista Colombiana de Ciência Animal, v.4, p.154-162, 2012.

PARTOS, L. FAO: fish feed costs to remain high. 2010. Available at: <http://www.seafoodsource.com/newsarticledetail. aspx?id=4294998760> . Accessed on: 12 May 2013.

PEZZATO, L.E.; BARROS, M.M.; FRACALOSSI, D.M.; CYRINO, J.E.P. Nutrição de peixes. In: CYRINO, J.E.P.; URBINATI, E.C.; FRACALOSSI, D.M.; CASTAGNOLLI, N. (Ed.). Tópicos especiais em piscicultura de água doce tropical intensiva. São Paulo: Sociedade Brasileira de Aqüicultura e Biologia Aquática, 2004. p.75-170. 
SANTOS, L.; PEREIRA FILHO, M.; SOBREIRA, C.; ITUASSÚ, D.; FONSECA, F.A.L. da. Exigência protéica de juvenis de tambaqui (Colossoma macropomum) após privação alimentar. Acta Amazonica, v.40, p.597-604, 2010. DOI: 10.1590/ S0044-59672010000300021.

SILVA, C.R.; GOMES, L.C.; BRANDÃO, F.R. Effect of feeding rate and frequency on tambaqui (Colossoma macropomum) growth, production and feeding costs during the first growth phase in cages. Aquaculture, v.264, p.135-139, 2007. DOI: 10.1016/j. aquaculture.2006.12.007.

TAVARES-DIAS, M.; MORAES, F.R. de. Hematologia de peixes teleósteos. Ribeirão Preto: M. Tavares-Dias, 2004. 144p.

TIAN, X.L.; QIN, J.G. A single phase of food deprivation provoked compensatory growth in barramundi Lates calcarifer. Aquaculture, v.224, p.169-179, 2003. DOI: 10.1016/S0044-8486(03)00224-2.

TURANO, M.J.; BORSKI, R.J.; DANIELS, H.V. Effects of cyclic feeding on compensatory growth of hybrid striped bass (Morone chrysops $\mathrm{x} M$. saxitilis) foodfish and water quality in production ponds. Aquaculture Research, v.39, p.1514-1523, 2008. DOI: 10.1111/j.1365-2109.2008.02023.x.
VERDOUW, H.; VAN ECHTELD, C.J.A.; DEKKERS, E.M.J. Ammonia determination based on indophenol formation with sodium salicylate. Water Research, v.12, p.399-402, 1978. DOI: 10.1016/0043-1354(78)90107-0.

WANG, Y.; LI, C.; QIN, J.G.; HAN, H. Cyclical feed deprivation and refeeding fails to enhance compensatory growth in Nile tilapia, Oreochromis niloticus L. Aquaculture Research, v.40, p.204-210, 2009. DOI: 10.1111/j.1365-2109.2008.02083.x.

WIESER, W.; KRUMSCHNABEL, G.; OJWANG-OKWOR, J.P. The energetics of starvation and growth after refeeding in juveniles of three cyprinid species. Environmental Biology of Fishes, v.33, p.63-71, 1992. DOI: 10.1007/BF00002554.

WILKIE, M.P. Ammonia excretion and urea handling by fish gills: present understanding and future research challenges. Journal of Experimental Zoology, v.293, p.284-301, 2002. DOI: 10.1002/ jez.10123.

WINTROBE, M.M. Variations on the size and hemoglobin content of erythrocytes in the blood of various vertebrates. Folia Haematologica, v.51, p.32-49, 1934.

Received on July 26, 2011 and accepted on July 22, 2013 